\title{
Record of Tubastraea coccinea on Xestospongia barrel sponge: a new threat to Caribbean and Gulf of Mexico reefs?
}
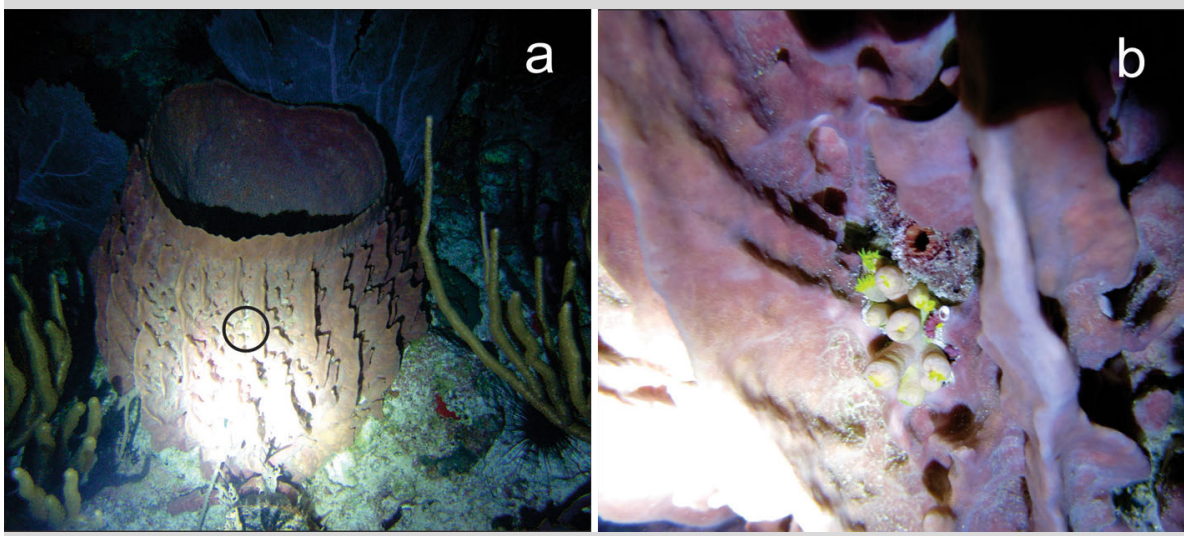

Fig. 1 a Barrel sponge Xestopongia muta (Schmidt, 1870) showing its vertical walls and crests, a suitable habitat for Tubastraea coccinea Lesson, 1829 colonization; b Tubastraea coccinea polyps on Xestospongia muta wall. Note at right and superior side of coral the presence of one Pyuridae Ascidiacea

Over the last 30 years, Tubastraea spp. has acquired the status of one of the most effective invasive species in the western Atlantic Ocean causing impacts in community structure, mortality of native corals, and the predation of both fish and invertebrate larva, with presumed effects on fishing yields (Creed et al. 2017; Miranda et al. 2018).

During sampling for the Marine Biodiversity of Yucatan (BDMY) project, seventy-nine sites on six reef areas at Cayos Oeste were surveyed during more than 320 team dives. One 10 polyp colony of Tubastraea coccinea Lesson, 1829 was recorded at Banco Obispo Sur; $(20.42535 \mathrm{~N} / 92.22692 \mathrm{~W})$ at a depth of approximately $15 \mathrm{~m}$. It was recorded deeply encrusted on the vertical outer wall of the barrel sponge Xestopongia muta (Schmidt, 1870) without any visible indication of necrosis on the sponge surface due to Tubastraea cnidocytes (Fig. 1). As T. coccinea could become very invasive in just few years after initial establishment (Creed et al. 2017), the colony was completely removed. To our knowledge, it is the first record of $T$. coccinea growing on living animals. The possibility of $T$. coccinea to colonize $X$. muta in the absence of other suitable substrates could favor its spread along reefs both on Gulf of Mexico and Caribbean, representing a threat to these areas.

Acknowledgements Thanks to Nuno Simões (UNAM) coordinator of the BDMY Project and its team and "Isla Mujeres" ship crew during field sampling. Funding by Comisión Nacional para el Conocimiento y Uso de la Biodiversidad (CONABIO; proyecto NE018) and Harte Research Institute Texas A\&M University at Corpus Christi (HRI-TAMUCC).

Compliance with ethical standards

Conflict of interest The author states that there is no conflict of interest.

\section{References}

Creed JC, Fenner D, Sammarco P, Cairns S, Capel K, Junqueira AOR, Cruz I, Miranda RJ, Carlos-Junior L, Mantelatto MC, Oigman-Pszczol S (2017) The invasion of the azooxanthellate coral Tubastraea (Scleractinia: Dendrophylliidae) throughout the world: history, pathways and vectors. Biol Invasions 19:283-305

Miranda RJ, Nunes J de ACC, Mariano-Neto E, Sippo JZ, Barros F (2018) Do invasive corals alter coral reef processes? an empirical approach evaluating reef fish trophic interactions. Mar Environ Res 138:19-27. https://doi.org/10.1016/j.marenvres.2018.03.013

L. F. Skinner (iD ( $₫)$

UERJ/DCIEN, Rua Francisco Portela 1470, São Gonçalo, RJ 24435-005, Brazil

e-mail: 1skinner@uerj.br 